TEME, г. XLI, бр. 3, јул - септембар 2017, стр. 673-685

Прегледни рад

Примљено: 22. 6. 2017.

DOI: $10.22190 /$ TEME1703673S

Одобрено за штампу: 19. 9. 2017.

\title{
ТРГОВИНСКА ЛИБЕРАЛИЗАЦИЈА И ЕКОНОМСКИ РАСТ: ПАНЕЛ-АНАЛИЗА НА ПРИМЕРУ НОВИХ ЧЛАНИЦА ЕВРОПСКЕ УНИЈЕ
}

\author{
Ненад Станишић", Ненад Јанковић, Гордана Миловановић \\ Универзитет у Крагујевцу, Економски факултет, Крагујевац, Србија \\ nstanisic@kg.ac.rs
}

\begin{abstract}
Апстракт
Спољнотрговинска либерализација један је од кључних елемената процеса економске транзиције у Европи. Упркос могућим негативним ефектима у кратком року и на одређене сегменте привреде, користи од спољнотрговнске либерализације, према класичној и неокласичној економској доктрини, далеко су веће за читаво друштво. Допринос либерализације трговинских токова убрзању економског раста предмет је истраживања у овом раду. Панел-регресиона анализа у овом раду је спроведена на примеру нових чланица ЕУ, а као мера степена трговинске либерализације коришћен је Индекс трговинских слобода The Heritage фондације. Peзултати указују на то да је пораст степена трговинских слобода негативно (а не позитивно) утицао на стопу раста реалног БДП. Резултат се показао као робустан са аспекта временског периода посматрања.
\end{abstract}

Кључне речи: економски раст, трговинска либерализација, транзиционе земље, нове чланице ЕУ.

\section{TRADE LIBERALIZATION AND ECONOMIC GROWTH: PANEL ANALYSIS ON THE CASE OF NEW EU MEMBER STATES}

\begin{abstract}
Trade liberalization represents one of the key policies in European transitional economies. In accordance with the classical and neoclassical economic paradigm, despite possible negative effects in the short run, and on the specific segments of the economy, the benefits from trade liberalization are larger to the whole society. The topic of this paper is the contribution of trade liberalization to the economic growth. Panel regression is conducted on the sample of new EU member states with the Index of trade freedom of The Heritage Foundation as a proxy for the level of trade liberalization. The results reveal that the increase of the index of trade freedom is associated with lower (but not higher) real GDP growth rates. The results are robust regarding the period observed.
\end{abstract}

Key words: economic growth, trade liberalization, new EU member states, transition. 
Динамичке промене у светској привреди последњих деценија све више заокупљају пажњу економске јавности. Јачање глобалних економских веза и све јаче повезивање земаља у јединствени светски привредни систем, поред великог броја присталица, наилази и на противнике, како у развијеним тако и у земљама у развоју. Преовлађујућа парадигма економског развоја заснованог на неолибералним схватањима тржишних слобода прихваћена је и у европским транзиционим земљама.

Стање економских слобода квантификује се помоћу Индекса економских слобода, који се годишње објављује од стране The Wall Street Journal and The Heritage Foundation. Подразумевају „основно право сваког човека да контролише, односно управља својим радом и имовином". У економски слободном друштву појединци су слободни да раде, производе, троше и инвестирају на начин на који то желе. Економске слободе требало би да доносе већи просперитет. Индекс економске слободе представља позитиван однос између економских слобода и разних позитивних друштвених и економских циљева. При томе, идеали економске слободе снажно су повезани са већим дохотком по становнику, развојем и елиминацијом сиромаштва. Према Heritage фондацији, Индекс економских слобода мери се помоћу 10 квантитативних и квалитативних фактора који су груписани у 4 шире категорије: владавина права (имовинска права, одсуство корупције), владина ограничења (фискална слобода, државна потрошња), регулаторна ефикасност (слобода пословања, слобода рада, монетарна слобода) и отворена тржишта (трговинска слобода, инвестициона слобода и финансијска слобода). Свака од економских слобода у овим категоријама оцењује се на скали од 0 до 100. Укупна оцена једне земље добија се када се израчуна просек ових десет економских слобода (пондер сваког фактора има исту вредност) (http://www.heritage.org/index/about).

Отварање тржишта се у преовлађујућој доктрини економске транзиције у Европи сматра једним од основних стубова изградње успешне тржишне економије. Емпиријско испитивање везе између либерализације спољнотрговинских токова, као једног аспекта повећања економске отворености земље и економског раста, предмет је емпиријске анализе овог рада. Конкретно, у раду ће бити анализиран однос између трговинске слободе (један од Индекса економских слобода Heritage фондације) и реалног раста БДП у 10 нових чланица ЕУ (НМС), у периоду од 1996. до 2015. године: Пољска, Чешка, Мађарска, Словачка, Естонија, Летонија, Литванија, Словенија, Бугарска и Румунија. Према Heritage фондацији, трговинска слобода је композитна мера одсуства царинских и нецаринских баријера које утичу на увоз и извоз робе и услуга. Резултат трговинских слобода 
заснива се на два улаза - пондерисаној просечној царинској тарифи и нецаринским баријерама (http://www.heritage.org/index/trade-freedom).

Сходно наведеном, истраживачка хипотеза гласи: Раст спољнотрговинске отворености земље, мерен индексом трговинских слобода, доприноси економском расту земље.

Остатак рада састоји се из три одељка и закључних разматрања. У следећем одељку рада представљен је преглед постојеће научне литературе у којој је преиспитивана веза између спољнотрговинске либерализације и економског раста. Након представљања методологије и примењених економетријских метода истраживања у овом раду, следи представљање и дискусија резултата.

\section{ПРЕГЛЕД ЛИТЕРАТУРЕ}

Сматра се да ниједна земља не може да функционише самостално зато што није у могућности да произведе све што је потребно њеном становништву и привреди. Из тог разлога, спољна трговина, односно отвореност земље и њена укљученост у међународне токове, може бити значајна за њен економски раст и развој. Ниво тог значаја зависиће од много фактора - величине тржишта, расположивости и разноврсности ресурса, степена развоја привреде, привредне структуре, њене економске политике, кретања на светском тржишту... По правилу, значај спољне трговине већи је за мање него за веће земље (имају велико домаће тржиште и разноврсне и обимне ресурсе). Ниво отворености мерен учешћем спољне трговине у БДП већи је код малих земаља. Подаци Светске трговинске организације из 2013. године потврђују овај закључак - стопа отворености Бразила је 24\%, САД-а 30\%, Јапана 32\%, Индије 51\%, Русије 52\%, док је ова стопа у Швајцарској 117\%, Словенији 140\%, Холандији 154\%, Белгији 165\%, Естонији 185\% и Сингапуру $400 \%$ (Крајишник \& Томаш, 2014, стр. 132-133).

Другу половину двадесетог века обележио је знатно већи раст светске трговине од раста светског БДП-а (нарочито ако се посматра БДП по становнику). Та разлика нарочито долази до изражаја уколико се посматра период од 1973. до 2001. године - обим светског извоза растао је 5,25\% просечно годишње, а БДП по становнику свега 1,4\% просечно годишње. Може се поставити питање да ли, и у којој мери, трговина стимулише економски раст (Николић, 2005, стр. 145).

Формирање међународних институција после Другог светског рата од стране економски најјачих земаља имало је за циљ убрзани развој међународних економских односа. Требало је у то ,јединствено" светско тржиште уклопити и земље у развоју. Коначни распад колонијалног система створио је предуслове за бржи економски развој већег дела светске популације. У суштини, постојале су две развојне 
стратегије: увозно-супститутивна и извозно оријентисана. Теоријски посматрано, обе стратегије могу да дају резултате, међутим, емпиријски гледано, земље које су изабрале извозну стратегију знатно су се брже развијале. На основу тога, многи истраживачи верују да је повећано учешће у међународној економији било примарни извор раста у многим земљама источне Азије (,азијски тигрови” 1970-их година, па и Кина, Индија 1980-их година) које су доживеле брз економски развој током последњих 50-ак година. Значајне стопе раста повезиване су са земљама које су прихватиле процес глобализације, повећале отвореност за међународну размену роба и услуга, прихватиле нове идеје и технологије. Емпиријска истраживања указала су на значајан и позитиван утицај отворености привреде на економски раст тих земаља. При томе, раст и развој немају битнији и јасан утицај на економску неједнакост унутар земље. Као резултат наведених чињеница, отвореност привреде према светском тржишту роба, услуга и капитала означена је као битан и неопходан аспект развојне стратегије и редукције сиромаштва у земљама у развоју (Станишић, 2004, стр. 121). Међутим, нико са сигурношћу не може да тврди колико је јака корелација између отворености и економског раста и да ли је либерализација међународне трговине довољна да обезбеди одрживо побољшање услова живота у земљама у развоју (Anderson \& Babula, 2008, str. 2-3).

Једноставно, поред свега, не може се рећи да је отвореност привреде била довољан фактор за успех наведених земаља. Кључ успеха био је у знатно дубљим и свеобухватнијим реформама привредног система, чији су међународни економски односи били само један део (Станишић, 2004, стр. 121). Из тог разлога, за земље у развоју, па и Србију (као једну од њих), веома је битан опрезан приступ, тј. потребно је да се пре смањивања трговинских рестрикција (повећања отворености привреде) обезбеди стабилан и недискриминаторан девизни курс, спроводи адекватна, неекспанзивна монетарно-фискална политика, смањи корупција, поправи пословна клима како би ефекти либерализације имали дугорочно позитивно дејство, односно како би дошло до убрзања привредног раста.

Међу економским истраживачима не постоји јединство о статистичкој значајности трговинске либерализације и економског раста. Према Болдвину (Baldwin), основни узрок несугласица је различит начин посматрања појма трговинске либерализације, због чега се и добијају различити резултати. Док Родригез и Родрик (Rodriguez \& Rodrik) инсистирају на вези између елиминисања трговинских баријера и привредног раста, већина других аутора „проблем” посматра знатно шире од примене мера трговинске политике. Међутим, ниједна промена у економској политици није корисна (или штетна) у свим околностима, тако да не треба да чуди то што успех трговинске 
либерализације није увек у потпуности известан. Позитивни ефекти трговинске либерализације биће у великој мери извесни само у адекватној комбинацији са осталим политикама и факторима (Станић, 2002, стр. 15-16).

Багвати (Bhagwati) сматра да они који тврде да ће слободна трговина у сваком случају довести до већег раста, или не познају фине нијансе теорије и знатан део литературе који је у супротности са овом тврдњом, или своје аргументе темеље на другачијим основама - у послератном периоду, највећи део доказа потврдио је да слободнија трговина на крају доводи до већег раста. Дакле, слично претходној констатацији, тамо где теорија обухвата неколико модела који могу ићи у различитим смеровима потребно је изабрати модел који је најприкладнији за стварност са којом се земља у том тренутку суочава. Према Багватију, на почетку XXI века потребно је било имати приступ који ствара повољне резултате за раст кад се трговина либерализује (Bhagwati, 2006, str. 61).

Доврик и Голи (Dowrick i Golley) закључили су да отвореност привреде промовише економски раст и да повећање трговине, у просеку, има директне и одрживе користи за економски раст. Ови ефекти најчешће се исказују кроз раст стопе продуктивности, са незнатним утицајем кроз инвестициони канал. Углавном, користи од раста трговине зависиле су од степена развоја, трговинске специјализације и временског периода посматрања. Током 1960-их и 1970-их година мање развијене земље биле су способне да усвоје напредније технологије кроз трговину. Међутим, могућност значајног раста продуктивности није била доступна оним земљама које су биле специјализоване у пољопривреди и рударству. Током 1980-их и 1990-их година ефекти отворености били су мањи него у претходном периоду и отвореност се у већој мери позитивно одразила на развијене земље (Dowrick \& Golley, 2004. p. 53).

Де Хан и Стурм (De Haan i Sturm) испитивали су утицај економских слобода на економски раст и том приликом користили су показатеље Heritage фондације и Fraser института. Њихов главни закључак је да више економских слобода подстиче економски раст, али да ниво слободе није повезан са растом. Другим речима, њихови резултати указују на то да ће више економских слобода брже довести земљу на стабилан ниво економског раста уколико се налазе испод њега, али да тај ниво стабилног економског раста не зависи од нивоа економских слобода. Ови налази нису у потпуности у складу са погледом заговорника либерализације (de Haan \& Sturm, 2000. p. 238).

Николић, Цветковић и Јевтић закључују да дејство трговинске политике, односно увозног протекционизма, на економски раст у великој мери зависи од услова - протекционизам може бити и кочница и стимулатор раста. Историјски посматрано, протекционизам код од- 
ређених сектора може дугорочно стимулисати раст (чак и укупни (агрегатни) економски раст). Са друге стране, на основу до сада урађених истраживања може се закључити да не постоји потпуно јасан став о међусобном односу спољне трговине и раста (иако већи број студија показује позитивну и статистички умерено значајну везу), тако да није добро олако фаворизовати ни либерализацију без уверљивих доказа, што значи да је потребан један опрезнији приступ. Поред спољнотрговинске размене, поставља се питање у којој мери трговинска регулатива и институционални оквир могу дати свој допринос убрзању привредног раста. Према истраживањима, половина утицаја повећане трговинске отворености на раст иде преко повећаних инвестиција (повећана профитабилност), а друга половина преко повећане продуктивности (специјализација, трансфер технологија). При томе, раст је био већи код мање развијених земаља (Кина, Индија..), чиме се потврђује да је за ове земље од изузетне важности трансфер технологије из богатих земаља. У земљама са лошим институцијама трговина има значајан утицај на раст зато што охрабрује регулаторне реформе и води вишој специјализацији. При томе, повећана отвореност у превише регулисаним економијама не може да надомести утицај лоших институција и може да доведе до негативних ефеката. Могуће је да пораст трговине утиче на земљу да ослаби регулацију како би се смањили повећани трошкови превелике регулације. Истовремено, домаћи и страни инвеститори могу „притискати” владу да побољша институције. Закључак би био да су за раст институције важније у дугом року, а отвореност (трговина) у средњем року (Николић, Цветковић \& Јевтић, 2010, стр. 118-119).

Гринвеј, Морган и Рајт (Greenway, Morgan i Wright) закључују да либерализација може повољно утицати на раст реалног БДП-а по становнику. Међутим, ефекти заостају и релативно су скромни. То не представља изненађење с обзиром на то да се либерализација разликује и по дубини и по интензитету и никад се не може рачунати на непосредну промену у правцу слободне трговине. Либерализациja, која је изабрана, често је први, уместо да буде завршни корак. Најмање четири фактора објашњавају зашто је претходна литература која се бавила утицајем либерализације на раст недоследна: величина и састав узорка, као и методолошки приступи - варирају; различити аналитичари користили су различите мере - неке су ex ante индикатори либерализације, неке су ex post, а друге су јасни индикатори отворености (Greenway, Morgan \& Wright, 2002, p. 243).

У свом раду је Стенснес (Stensnes) истраживао везу између економске отворености, институција и раста. У закључку, хипотеза је потврђена - како би се искористиле све предности интеграције у глобална тржишта, добре институције за управљање конфликтима су неопходне. Те предности могу бити искоришћене кроз свеобухватан 
приступ дизајнирању трговинске политике, узимајући у обзир и тренутни статус и унапређење потенцијала институционалног квалитета. Међутим, проблем је што тачни, конкретни кораци који воде до таквог побољшања у литератури нису јасно дефинисани. Жељени механизми за управљање конфликтима могу бити постигнути кроз различите типове институционалних аранжмана, са могућим простором за прилагођавање конкретним земљама. Општа порука доносиоцима политика је да су институције за управљање конфликтима приоритет и да су даља истраживања неопходна како би било могуће наћи решење и за специфичне политике (Stensnes, 2006, pp. 55-56).

Хачет-Бордон, Ли Моел и Вијил (Huchet-Bourdon, Le Mouel, i Vijil) такође су у свом раду истраживали везу између трговинске отворености и раста. Почевши од идеје да се трговинска отвореност не може приказати само кроз трговинске токове, предложили су да се као две додатне димензије за трговинску интеграцију земаља рачунају квалитет и разноврсност извоза. Уколико се посматра утицај трговинске отворености на раст и у обзир узме квалитет извоза, долази се до интересантног нелинеарног обрасца - трговина може имати негативан утицај на раст када су земље специјализоване за производе ниског квалитета; трговина јасно појачава раст једино у земљама које су специјализоване за производе високог квалитета и њихова извозна корпа показује минимални потребни ниво квалитета. Што је већи квалитет извозне корпе - то је већи и утицај извоза на раст. Резултати такође показују нелинеаран однос између трговине и раста када се узме у обзир разноврсност извоза. Међутим, утицај повећања разноврсности извоза на раст је позитиван до одређеног степена зависности економије од извоза. За већину земаља у развоју нађен је образац комплементарности између зависности од трговине и разноврсности - извозни рацио има позитиван утицај на БДП по становнику и што је већа разноврсност извозне корпе - то је већи утицај трговинског рација. Из перспективе економске политике, ови резултати веома су занимљиви јер показују да улагање у производне капацитете које подиже квалитет извоза земаља у развоју може бити одлучујуће за подстицање раста. При томе, олакшан приступ извозном тржишту новим извозницима, промовисање извоза путем агенција такође може имати значајне импликације за развој (Huchet-Bourdon, Le Mouel \& Vijil, 2011, pp.18-19).

Упркос бројним емпиријским истраживањима, јединствен став о доприносу трговинске либерализације економском расту земље не постоји. Резултати варирају у зависности од специфицираног модела, примењене методологије и економетријских метода, избора узорка земаља и анализираног временског периода. Имајући у виду да скоро и не постоје радови који степен спољнотрговинске либерализације мере Индексом трговинских слобода Heritage фондације, употреба управо овог индекса у ту сврху чини овај рад специфичним. 


\section{ПОДАЦИ И МЕТОДОЛОГИЈА}

Однос између економског раста и трговинских слобода се у овом раду испитује на узорку од 10 земаља, тзв. Нових чланица ЕУ, у периоду од 1996. до 2015. године. Економски раст је мерен као годишња стопа промене реалног БДП-а (БДП у сталним ценама). Подаци су преузети из базе Светске банке - World Development Indicators. Варијабла која изражава степен трговинских слобода је Индекс трговинских слобода The Heritage фондације.

Основна истраживачка хипотеза у раду је економски раст у директној вези са степеном трговинских слобода:

$$
\text { GROWTH }_{i, t}=f\left(\mathrm{TF}_{\mathrm{i}, \mathrm{t}-1}, \mathrm{Z}_{\mathrm{i}, \mathrm{t}-\mathrm{1}}\right) \text {, }
$$

где:

- GROWTH $_{\mathrm{i}, \mathrm{t}}$ представља стопу раста реалног БДП-а у земљи $i$, у години $t$;

- $\mathrm{TF}_{\mathrm{i}, \mathrm{t}-1}$ је вредност Индекса трговинских слобода за земљу $i$ у години $t-1$;

- $\mathrm{Z}$ представља вектор контролних варијабли у моделу.

Контролне варијабле у моделу су индекси економских слобода The Heritage фондације (осим Индекса трговинских слобода), конкретно: индекс монетарних слобода (MF), индекс фискалних слобода (FF), индекс јавне потрошње (GS), индекс пословних слобода (BF), индекс инвестиционих слобода (IF), индекс финансијских слобода (FINF), индекс имовинских права (PRF), индекс степена корупције (CF) и индекс радних слобода (LF).

Сходно методологији The Heritage фондације за израчунавање индекса економских слобода, сви индекси су пондерисани и нормализовани како би се обезбедила једнака важност сваког од индекса у економетријским и статистичким истраживањима. Сваки индекс изражава се на скали од 0 до 100, где 100 представља максималну, тј. потпуну слободу.

Како је очекивано да сваки од десет наведених индекса економских слобода утиче на економски раст, основна истраживачка хипотеза у овом раду је да индекс трговинских слобода утиче на стопу раста реалног БДП-а, ceteris paribus.

У складу са специфицираним истраживачким моделом (Eq. 1), дефинисана је следећа панел-регресиона једначина:

где:

$$
G R O W T H_{i, t}=\alpha_{0}+\alpha_{1} T F_{i, t-1}+\sum_{k=2}^{9} \alpha k Z_{i, t-1}+u_{i, t},
$$

- GROWTH $\mathrm{H}_{\mathrm{i}, \mathrm{t}}$ представља стопу раста реалног БДП-а у земљи $i$, у години $t$;

- $\mathrm{TF}_{\mathrm{i}, \mathrm{t}-1}$ је вредност Индекса трговинских слобода за земљу $i$ у години $t-1$; 
- $Z_{i, t-1}$ је $1 \mathrm{x} 8$ вектор контролних варијабли (MF; $F F ; G S ; B F ; I F$; FINF; PRF; CF).

Временски период означен је са $t=1996, \ldots 2015$, а земље узорка са $i=1, \ldots 11$.

Индекс радних слобода LF изостављен је из анализе због недостајућих података. Све независне варијабле су са временским заостатком од једне године. На основу расположивих података, формиран је у потпуности избалансиран панел са 200 (10х20) опсервација. Табели 1.

Дескриптивна статистика свих варијабли представљена је у

Табела 1. Дескриптивна статистика

\begin{tabular}{lcc}
\hline Варијабла & Ар. средина & Ст. девијација \\
\hline GROWTH & 3,31 & 4,20 \\
PRF & 54,60 & 15,16 \\
CF & 45,61 & 10,62 \\
FF & 72,51 & 12,11 \\
GS & 46,97 & 15,61 \\
BF & 71,31 & 9,63 \\
MF & 71,25 & 16,90 \\
TF & 78,60 & 10,00 \\
IF & 68,10 & 12,44 \\
FINF & 65,00 & 14,39 \\
\hline
\end{tabular}

Имајући у виду природу посматраних варијабли, могућ је проблем аутокорелације. Такође, сама The Heritage фондација упозорава да је могуће да су индекси економских слобода међусобно корелирани. Како би се пронашли узроци и предупредили могући проблеми у регресионој анализи, израчуната је корелациона матрица независних варијабли (Табела 2).

Табела 2. Корелачиона матрииа независних варијабли

\begin{tabular}{|l|c|c|r|r|r|r|r|r|r|}
\hline & PRF & CF & FF & GS & BF & MF & TF & IF & FINF \\
\hline PRF & 1,00 & 0,64 & $-0,10$ & $-0,26$ & 0,51 & 0,19 & 0,14 & 0,60 & 0,52 \\
\hline CF & & 1,00 & $-0,06$ & $-0,23$ & 0,46 & 0,30 & 0,24 & 0,46 & 0,26 \\
\hline FF & & & 1,00 & 0,48 & 0,20 & 0,35 & 0,47 & 0,30 & 0,30 \\
\hline GS & & & & 1,00 & 0,04 & $-0,10$ & 0,18 & 0,13 & $-0,02$ \\
\hline BF & & & & & 1,00 & 0,34 & 0,34 & 0,49 & 0,39 \\
\hline MF & & & & & & 1,00 & 0,48 & 0,20 & 0,44 \\
\hline TF & & & & & & & 1,00 & 0,46 & 0,25 \\
\hline IF & & & & & & & & 1,00 & 0,44 \\
\hline FINF & & & & & & & & & 1,00 \\
\hline
\end{tabular}


Како би се избегао могући проблем мултиколинеарности, а на основу резултата корелационе матрице, из модела је избачен индекс имовинских права PRF, услед постојања високе корелираности ове варијабле са индексом корупције CF, индексом пословних слобода $\mathrm{BF}$, индексом инвестиционих слобода IF и индексом финансијских слобода FINF (вредност индекса корелације изнад 0,5 ).

Постојање јединичног корена у временским серијама података (што такође представља ограничење примене панел-регресионе анализе) тестирано је употребом Levin-Lin-Chu testa (Levin, A., C.-F. Lin, \& C.-S. J. Chu, 2002). Резултати теста указују на то да су варијабле GROWTH, TF, MF и FF стационарне, тј. да немају јединични корен. Са друге стране, из разлога нестационарности, из модела су изостављене следеће варијабле: CF, GS, BF, IF, FINF (резултати LLC теста дати су у Прилогу).

\section{РЕЗУЛТАТИ}

У циљу испитивања утицаја економске кризе на однос између трговинских слобода и економског раста, панел-регресија урађена је за три различита периода: 1996-2015. (Модел 1), преткризни период 1996-2008. (Модел 2) и период 2000-2008. (Модел 3).

Резултати спроведеног Хаусман теста (Hausman, J. А., 1978) определили су употребу панел-анализе са фиксним ефектима (насупрот одбаченом моделу са случајним ефектима). Табели 3.

Резултати панел-регресионе анализе представљени су у

Табела 3. Резултати панел-регресије

\begin{tabular}{lcccccc}
\hline & \multicolumn{2}{c}{ Model 1 } & \multicolumn{2}{c}{ Model 2 } & \multicolumn{2}{c}{ Model 3 } \\
& $(1996-2015)$ & $(1996-2008)$ & $2008)$ \\
\hline Variables & coefficient & prob. & coefficient & prob. & coefficient & prob. \\
const. & 8.793 & 0.001 & -3.951 & 0.149 & 8.793 & 0.001 \\
Trade freedom & -0.188 & 0.000 & -0.069 & 0.096 & -0.188 & 0.000 \\
Monetary freedom & 0.083 & 0.003 & 0.035 & 0.100 & 0.083 & 0.003 \\
Fiscal freedom & 0.046 & 0.263 & 0.164 & 0.000 & 0.046 & 0.263 \\
\hline R squared & 0.27 & & 0.58 & & 0.69 & \\
F stat. & 11.78 & 0.0000 & 7.34 & 0.0000 & 9.14 & 0.0000 \\
\hline
\end{tabular}

На основу приказаних резултата панел-регресије, пораст индекса трговинских слобода негативно утиче на стопу раста реалног БДП-а у сва три спецификована модела (1996-2015, 1996-2008, и 2000-2008). Коефицијент уз варијаблу Индекс трговинских слобода негативан је и статистички значајан у свим тестираним моделима. Насупрот томе, уз две контролне варијабле (Индекс монетарних слобода и Индекс фискалних слобода), коефицијент је позитиван у сва три модела, што 
указује на позитиван утицај пораста наведених индекса на стопу економског раста.

\section{ЗАКЉУЧАК}

Либерализација тржишта, укључујући либерализацију спољнотрговинских токова, представља један од основних постулата неолибералног схватања и парадигме економског развоја која преовлађује у европским транзиционим земљама. Предмет истраживања у овом раду управо је допринос спољнотрговинске либерализације економском расту, на узорку десет нових чланица ЕУ (НМС) у периоду од 1996, до 2015. године. Као квантитативна мера степена трговинске либерализације употребљен је индекс трговинских слобода The Heritage фондације, што овај рад чини другачијим од многих других са сличном тематиком.

Резултати засновани на примењеном методу панел-регресија нису потврдили основну истраживачку хипотезу рада да раст степена спољнотрговинске либерализације доприноси порасту стопе економског раста. Управо супротно, регресиони резултати говоре у прилог чињеници да је пораст степена трговинске отворености земље повезан са падом стопе економског раста. Овакав резултат је робустан у односу на спецификовани период посматрања, тј. потврђен је како у целокупном посматраном периоду (1996-2015) тако и у периодима пре кризе (1996-2008) и у периоду значајног економског раста 2000-2008.

Немогућност довођења у везу раста степена трговинских слобода са порастом стопе економског раста свакако се не може тумачити као доказ негативног утицаја спољнотрговинске либерализације на економски раст. Могуће је да такав утицај постоји у почетним стадијумима либерализације, али да са даљим растом степена либерализације тржишта утицај ишчезава. С друге стране, овакав резултат може ићи у прилог тези негативног деловања брзе либерализације, каква је спроведена у већини европских транзиционих земаља. Управо покушај да се квантитативним методама преиспитају две наведене претпоставке може представљати правац неких будућих истраживања.

\section{ЛИТЕРАТУРА}

Anderson, L., \& Babula, R. (2008). The Link Between Openness and Long-Run Economic Growth, Journal of International Commerce and Economics, United States International Trade Commission, pp. 1-20.

Bhagwati, J. (2006). Слободна трговина данас, Графички завод Хрватске, Загреб. de Haan, J., \& Sturm, J-E. (2000). On the relationship between economic freedom and economic growth, European Journal of Political Economy Vol. 16, Elsevier, pp. 215-241. 
Dowrick, S., \& Golley, J. (2004). Trade Openness and Growth: Who Benefits?, Oxford Review of Economic Policy 20(1), Oxford Academic, pp. 38-56.

Greenway, D., Morgan, W., \& Wright, P. (2002). Trade liberalization and growth in developing countries, Journal of Development Economics Vol 67, Elsevier, pp. 229-244.

Hausman, J. A. (1978). Specification tests in econometrics. Econometrica 46: 1251-1271.

Huchet-Bourdon, M., Le Mouel, C., \& Vijil, M. (2011). The relationship between trade openness and economic growth: Some new insights on the openness measurement issue, XIIIeme Congres de l'Association Europeenne des Economistes Agricoles.

Крајишник, М., \& Томаш, Д. (2014). Утицај спољне трговине на привредни раст Републике Српске, Acta Economica, година XII, број 20, Економски факултет Универзитета у Бањој Луци, стр. 125-153.

Levin, A., C.-F. Lin, \& C.-S. J. Chu. (2002). Unit root tests in panel data: Asymptotic and finite-sample properties. Journal of Econometrics, 108: 1-24.

Николић, Г. (2005). Утицај спољне трговине на економски раст, Економски анали, бр. 165, Економски факултет, Београд, стр. 145-164.

Николић, Г., Цветковић, С., \& Јевтић, Ж. (2010). Ефекат економске отворености на привредни раст - случај СФРЈ и импликације на Србију данас, Индустрија, бр. 3, Економски институт, Београд, стр. 107-120.

Станишић, Н. (2004). Глобализација и сиромаштво, Економски хоризонти, 1-2, Економски факултет Универзитета у Крагујевцу, стр. 121-134.

Станић, К. (2002). Трговинска либерализација и економски раст - зависност успеха од комплементарних политика и природних баријера, Индустрија, 14, Економски институт, Београд, стр. 13-21.

Stensnes, K. (2006). Trade Openness and Economic Growth Do Institutions Matter? Norwegian Institute of International Affairs,

http://www.heritage.org/index/about, 13. 2. 2017. године

http://www.heritage.org/index/trade-freedom, 13. 2. 2017. године.

\section{TRADE LIBERALIZATION AND ECONOMIC GROWTH: PANEL ANALYSIS ON THE CASE OF NEW EU MEMBER STATES}

Nenad Stanišić, Nenad Janković, Gordana Milovanović

University of Kragujevac, Faculty of Economics, Kragujevac, Serbia

\section{Summary}

Trade liberalization is considered one of the key economic policies in European transitional economies contributing to the development of the emerging market economy. The relationship between trade liberalization and economic growth is empirically tested in this paper. The Index of trade freedom of The Heritage foundation is used as a measure of the trade liberalisation, while the economic growth is measured by the growth rate of the real GDP. According to the Heritage foundation, trade freedom is a composite measure of (un)existence of tariff and non-tariff trade barriers for exports and imports of goods and services. The trade freedom score is a result of two inputs: weighted trade tariffs rate and level of non-tariff trade barriers. The relationship between trade freedom and economic growth is tested on the sample of 10 new EU member 
states (NMS) during the period 1996-2015: Poland, Czech Republic, Slovak Republic, Hungary, Estonia, Latvia, Litvania, Slovenia, Romania, and Bulgaria.

The results of the conducted panel regression analysis did not confirm the main hypothesis that the increase of trade liberalization contributes to the increase of the growth rate. Contrary, the results revealed a negative relation, i.e. that the countries with a higher level of trade freedom experienced a lower economic growth rate. This result confirmed to be robust regarding the period, i.e. it is confirmed in three different periods: whole observed period 1996-2015, pre-crisis period 1996-2008, and strong economic growth period 2000-2008.

Observed nonexistent positive relationship between trade liberalization and economic growth should not be considered as a proof of a negative influence of trade liberalization on the economic growth. It is possible that positive influence exists in the early stages of trade liberalization, while diminishing afterwards. On the other hand, this result could be a consequence of a relatively fast trade liberalization, which is observed in most of the European transitional economies. 